Pakistan Journal of Humanities and Social Sciences

April - June 2019, Volume 7, No. 2, Pages 167 - 183

\title{
Liquidity Risk Management in Banking Sector under the Shadow of Systematic Risk and Economic Dynamics in Pakistan
}

\author{
Hafiz Waqas Kamran ${ }^{1}$, Dr. Abdelnaser Omran ${ }^{2}$, Dr. Shamsul Bahrain bin Mohamed \\ Arshad $^{3}$ \\ ${ }^{1,3}$ School of Economics, Finance and Banking, College of Banking, Universiti Utara \\ Malaysia, Sintok, 06010, Kedah State, Malaysia \\ ${ }^{2}$ Faculty of Engineering Sciences, Bright Star University, El-Breqa, Libya \\ Email: hafizwaqaskamran@gmail.com
}

\begin{abstract}
The aim of this present study is to investigate the impact of systematic risk and economic dynamics on liquidity reserve of banking firms in Pakistan. Data for stock return and market return is collected from Data stream, while for all other factors World Development Indicator (WDI) database is selected. The findings of Pooled Regression have suggested that Liquidity Reserves for overall banking Industry of Pakistan significantly affect by Systematic Risk and Key Economic Dynamics. Panel data Models are applied to check whether there is cross sectional heterogeneity in selected financial firms or not. The study period consists of last 15 years 2001-15, due to the availability of the data set. Moreover, other economic indicators like Lending Interest Rate and Inflation can be under observation for the future studies. As per the best perception of researchers, this is the first study in this context, addressing the Liquidity Management and selected key factors.
\end{abstract}

Keywords: Liquidity Reserve, WDI, Panel Data Models, Systematic Risk, Pakistan

\section{Introduction}

After the World Financial Crisis (WFC) of 2008-09, a global perspective of liquidity monitoring and management with the risk mitigation approaches has emerged for the overall financial stability of banking firms. For this purpose,strong rules and regulations have been defined and implemented in different regions Like USA (Wan, 2015) EU (Howarth \& Quaglia, 2016)and in the Asian region as well (Chalermchatvichien, Jumreornvong, \& Jiraporn, 2014). Even after the implementation of Basel Accord III at world Economy, the need of Liquidity Management is still a contemporary topic in existing body of literature. With the passage of time, changes in the Global Banking and Financial System have occurred 
in recent 02 decades with the solution for managing the liquidity risk, but such dramatic changes have increased the exposure of underestimation of such risk (Ruozi \& Ferrari, 2013). The last decade WFC has thrown light on the issue that much involvement is necessary by the regulatory bodies and corporate level authorities for liquidity management in the normal and stressful situation. Besides, WFC has also underlined the internal flaws and create a need for international regulations for managing such risk. Liquidity Management LM is a very much complex phenomenon as it depends on variety of internal and external factors as faced by the business organization. In a normal financial system, various key players like banking firms, insurance and leasing companies, mutual funds, Portfolio Management integrate with each where banking firm plays the most significant role. The concept of funding liquidity of banks means the ability of the firm to fulfill its obligation as it becomes due (Drehmann \& Nikolaou, 2013). The failure in fulfilling such obligations lead to the severe financial damages for the banks(Diamond \& Dybvig, 1983). In financial system, where securities are tradedon a daily basis, significant aspect of risk is systematic in nature and address in numerous earlier studies. Systematic risk is actually inherent risk of any of security which is estimated through the value of beta coefficient as proposed by (Jewczyn, 2013). The factor of beta is an important component in financial decision making and in defining the value of stock. The value of liquidity for the business firm can also be affected by the variety of risk factors including the systematic risk as well. Liquidity Management is a key challenge of any business concern as arrange of firm specific and country specific factors affect it where the importance of systematic risk cannot be ignored. From the context of Emerging Markets (EM), Macroeconomic, financial indicators are also playing their significant role in affecting the liquidity. Such factors specifically in EM are the structure of market, financial policies, trading infrastructure, regulatory framework, and financial innovation (Lesmond, 2005). From the context of Pakistan, the key market factors which can affect the Liquidity Management is Deposit Interest Rate DIR, claim on central government, domestic credit provided by Economic and Domestic Credit to Private Sector by Banks have been observed in the present study. Graph Below presents the trend of Bank Liquid Reserve to Bank Asset Ratio as key outcome factor over a period of study. 
Figure 1: Liquidity Reserve to Assets Ratio (\% of GDP) of Banking Sector in Pakistan

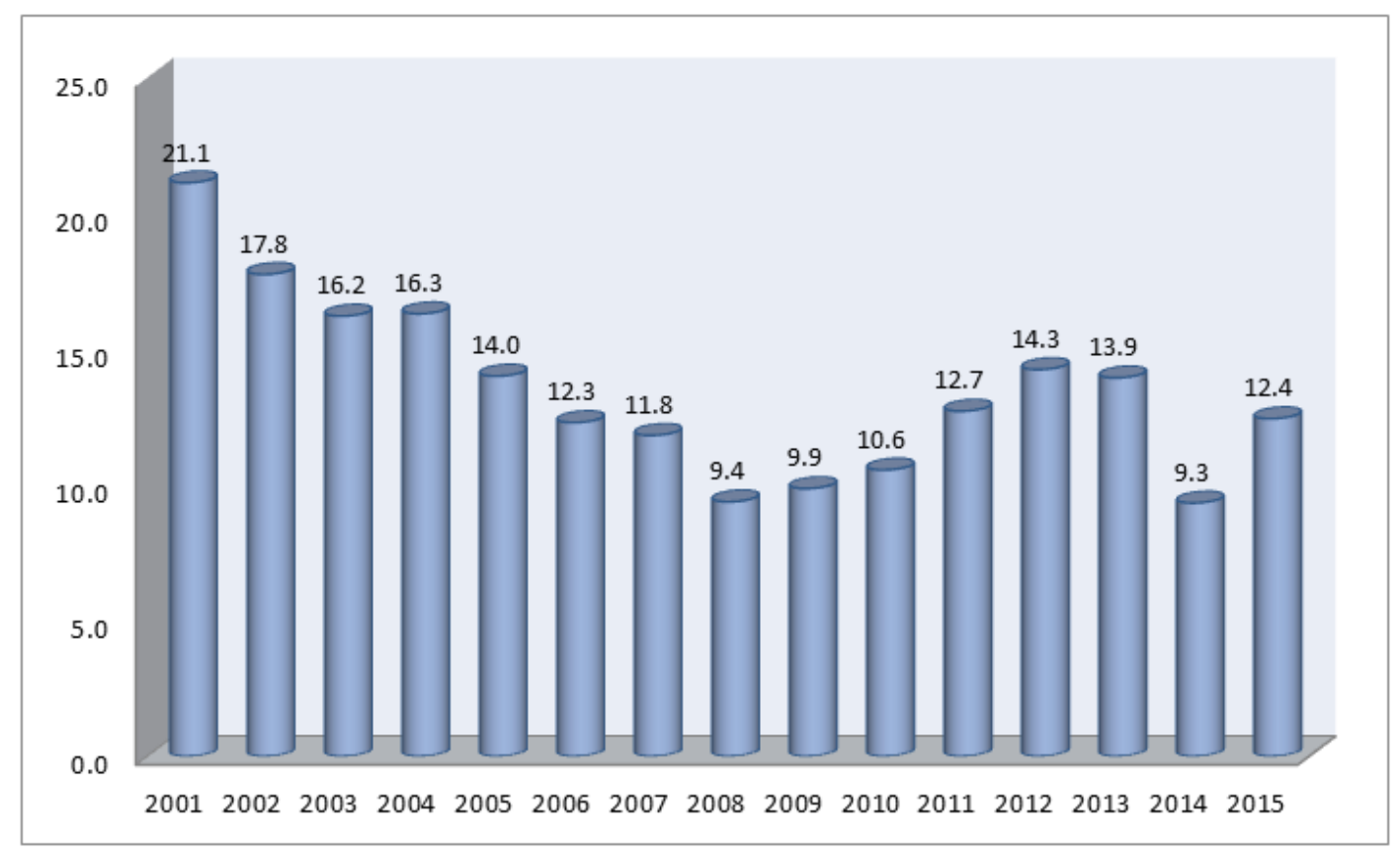

Source: World Bank Group

\section{Literature Review}

Liquidity and risk management related to it is always the main topic in the literature context of financial markets. From last many decades to now, various authors have provided their findings about liquidity risk management. Notables are (Akhtar et al. \& Sadaqat 2011, Bangia et al. \& Stroughair 2008, Barfield \& Venkat 2009, Vento \& La Ganga 2009). In the previous studies, significant contribution is made for the Liquidity and various indicators which are impacting on it. For instance, in the study of (Rubio, Rubio, Carrasco-Gallego, \& Carrasco-Gallego, 2016), they have examined the interaction of liquidity, interest rate and house prices in the Euro zone. They have found that the monetary policy, with the distorted house prices and shocks of technology, have a combined effect over the enhancement of the liquidity. The study of (Kuipers 1985) has linked the interest rate with the saving and liquidity shortage with the mixed stream of findings for conventional economics tenets and equilibrium theory as well. Linnemann and Schabert (2015) have also explored the relationship of liquidity premium and interest rate parity and found that liquidity premium leads to the modification of interest rate parity. In the crisis of banking system which observes though volatility and liquidity risk, the management of assets, liabilities, and risk remain the core and significant function of banking firm (Waemustafa \& Sukri 2016). By focusing on this point, 
they have studied the core determinants for the liquidity risk for both Islamic and Conventional Banking firms. For the overall economic activity credit is a vital component and borrowing for instance by the household for house construction, and similarly, business organization needs funds to invest (Dembiermont, Drehmann, \& Muksakunratana 2013). Additionally, they also have explained that credit facility to private sector will also increase the financial stability of the firms. But as per the importance, the more advancement in such format will lead to the systematic crisis by unusual buildups. As per the prime objective of banking firms is to provide the loan to the domestic clients which include several parties to deal with. Credit Risk in the Banking and Financial Firms also affects Liquidity Position as the presence of Non-Performing Loans and more provision to such account will adversely affect the financial health of the business(Arif \& Nauman Anees 2012). Higher Domestic Credit by Financial Institutions will create an imbalance for the Liquidity Management.

The liquidity concept for the bank becomes an important issue for the financial regulations as liquidity crunches become the major issue after the financial crisis of 2008-09. However, at the same point in time, it is quite uncertain that modern emphasizes on the liquidity funding and management will make the banking firms specially in US, having low probability of risk with the more stability of whole financial system. For this purpose, appropriate understanding for the linkage between the bank's risk-taking behavior and funding liquidity risk is of great importance. Liquidity risk has been recognized as one of the major threat to the various role players in financial markets and for stability as well(Khan et al. 2017). Systematic form of Liquidity risk was a key contributor to the failure of banking firms back in last decade just after financial crisis (Hong et al. 2014). Their findings further reveal the fact that through systematic and idiosyncratic channels liquidity risk can lead to the financial distress. Besides this argument one perception is that Deposit balance can secure the banking firms from the funding liquidity risk which leads to reduction in market discipline and leads to more risk-taking behavior of banks. To study the dynamics of investment and liquidity management for the firms known as Financial Constraints (FC), (Wu et al. 2017) have incorporated a model, predicting the outcome that traditional risk models for the business have ambiguous effect on the investment decision and Liquidity Management. The ratio of Firms cash to capital for the liquidity measurement. After the free movement of global capital to different regions, business firms have shown great focus for the concept of liquidity management. From the financial market perspective, a group of researchers who is involved with the liquidity risk has revealed the two crucial factors; movement between the 
individual stock liquidity and overall market liquidity (Sensoy 2017). In this context, the effect of liquidity for one firm cannot be ignored over to other participants in the same market as it has a spillover effect.

Over the last many decades, studies have linked the financial indicators to the Economics dynamics with the international comparison specifically. The study of (Arcand et al. 2015a, 2015b, Demirgüç-Kunt \& Levine 2008, King \& Levine 1993, Levine \& Zervos 1998) has covered such interactions. Liquidity Creation measures the output for the banking firm as the concept of Modern theory of Financial Intermediation; banks are responsible for the Creation of Liquidity and Transformation of the risk. As per the risk transformation theory, banking firms issue the deposits for financing the loans which are at risk all time. So, the liquidity creation is highly correlated with the outcome of risk transformation. The study of (Berger \& Sedunov 2017)has stated the fact that Bank's liquidity creation is a significant contributor for the real output in the economy in terms of GDP. Specifically, their findings suggest that small banking firms in the form of liquidity creation contribute more for the GDP per dollar than large bank Liquidity Creation. The management of Liquidity for the banking industry in the presence of various economic factors is an important task for the Management. The study of (DeYoung \& Jang 2016)has tested liquidity position of US commercial banking firms over three decades (1992-2012) before the implementation of Basel III regulations for the Managing Liquidity. The findings are consistent with those firms having targeted the liquidity to core Deposits (LTCD) ratios. But as the banking firms increase with size, lower targets for liquidity; the breach of upcoming Basel III rules of managing liquidity. Banks and liquidity are named which are closely linked because of information asymmetries between the borrowers and the lenders. By creating loans (not liquid) assets banking firms keep such asymmetries in both the parties and often such deposits are kept for such assets, but such mismatch creates the risk of liquidity for banks. As banking firms are integrated through branch networking and liquidity is transferred through payments which are known as real time gross settlements. For Liquidity Management LM, large banking firms face the query of how to generate and allocate the liquidity; either into a central or decentral location (Pokutta \& Schmaltz 2011).

Besides, the two economic aspects are required by the banks to keep the reserved in a desired level deposits, and same idea is explored by(Kane \& Muzere 2005) in their study. They state that reserve of banking firms can be a shield to mitigate the potential losses of liquidity risk and full fill the liquidity demand by depositors. They also reveal the fact that 
due to some transaction or information related costs, investors prefer the intermediary investment as compared to direct investment. For this issue, bankers offer their investors competitive returns on deposits, for the comparison of liquidation reserve to attract funds(Kane \& Muzere 2005).

The extension of literature for the liquidity also capture the three dimensions; Funding Liquidity (FL), Central Bank (CB) and Market Liquidity (ML). Nikolaou (2009)hadexplored this relationship with the idea that major cause of liquidity risk is of asymmetrical information and existence of incomplete market. However, he argues that CB liquidity is not a permanent solution but a temporary solution so that management of banking firms can identify and rectify the problem. Meanwhile, for the banks, FL is easy to define but same time is challenging to measure. FL Risk is stable and not high with the seasonal spikes in time of financial crisis (Drehmann \& Nikolaou 2013).

Study conducted by(Bryant 1980, Diamond \& Dybvig 1983) presume to be the foundation for the recent incarnation of the theme that bank creates liquidity. Their findings provide the idea that by financing illiquid assets banking firms provide liquidity on their balance sheet with high liquid liabilities relatively. Additionally, the connection of banks liquidity and capital has provided the empirical evidences. In last decade, (Deep \& Schaefer 2004) have explored the relative measure of liquidity transformation LT which is measured as ratio of difference between liquid liabilities and assets divided by total assets. Their findings suggest that for US banking firms, LT gap is almost $20 \%$ of assets and finally provide the argument that liquidity is not much created by US banking firms. In a conclusive approach, the existing literature has captured the various dimensions of liquidity risk, Liquidity management for the banking firms which provide the cash to the rest of economy and other key role players. So, the need of time is to explore the relationship between the important risk factors for the various financial sector role players; systematic risk, Liquidity Management by banks and those Economic Dynamics which have not got significant attention. So, in the present study, authors have explored such linkage to provide a new dimension to the existing body of literature and building of conceptual frameworks by exploring the unexplored.

\section{Conceptual Framework}

For both the risk professionals and researchers, liquidity risk has got significant attention after the recent financial crisis. Asa number of factors can have adverse as well as the positive affect on the liquidity of the Economics, which includes both from industry and 
the firm. For the better understanding of the study, researchers have developed the following conceptual framework (Figure 2).

Figure 2: Liquidity Management, Systematic Risk, and Economic Indicators Interaction

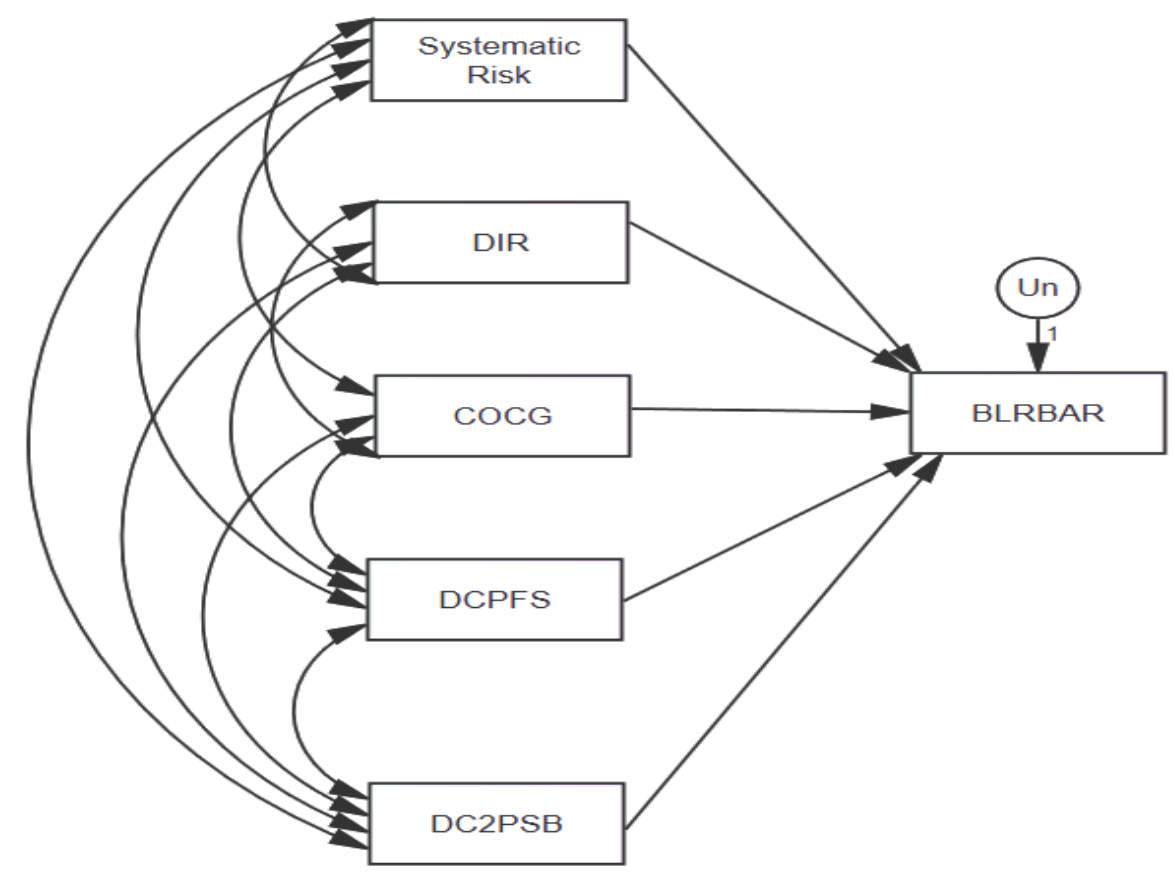

Source: The authors

\section{Variables of the Study}

\section{A. Systematic Risk}

The overall Risk of the firm in any of the security or financial asset can be divided into systematic and nonsystematic element. Systematic Risk is inherent risk in any of the investment mode and cannot eliminate through diversification. For the calculation of Systematic Risk, at first sample of 46 Economic firms have been considered based on the availability of the data in the period of study. After that the monthly stock return data for each of the firm over last 15 years is collected, with the overall Market return as Systematic Risk is calculated through both Factors. The factor which helps to calculate the Systematic risk is Beta which is relevant movement in asset return to the change in market return over time. Mathematically, the value of Beta is presented as follows:

$$
\mathrm{R} i=\beta o+\beta i \mathrm{R} m+\mathrm{e} i
$$

In equation, the value of $\mathrm{Ri}$ indicates the return of the business firm which has a linear association with the overall return trend of the market $\mathrm{Rm}$ with the value of error term ei. As 
per the findings of (Logue \& Merville, 1972), the value of calculated beta is symmetrical to the actual value of beta; which cannot be measured. In the present study, the researchers have calculated the value of beta for all the selected firms from the Economic as consider it as a main explanatory factor which can affect the Liquidity Management.

\section{B. Deposit Interest Rate (DIR)}

The value of Deposit Interest Rate indicates the rate of interest paid by the financial institutions working in overall financial market to the account holders who have deposited their money in saving accounts, COD or certificates of deposits and similar other accounts. Deposit Accounts are attractive places for the submission of excessive funds by the fundholders who need a safe side for their principle amount and reasonable earning with it (Investopedia, 2017). The value of DIR can affect the Liquidity Management decision by the firm or a state either in positive or negative way. For the stability of financial Institution, DIR can be considered as a main indicator (Diamond \& Dybvig, 1983). The data for DIR is collected from Official Web Site of World Bank (World Development Indicator WDI).

\section{Claims on Central Government (COCG)}

Financial institution working either in the domestic market or international environment provides the amount of loan to arrange of clients. The main parties who get the loan from member Financial Institutions are individuals, companies and Govt. bodies. Claim on Central Government represents the amount of loans given to Central Government Institutions as net of the deposits, which holds a major portion of overall advances. Such claims are the deposits of financial institutions and in the present study; researcher has considered its value as 2nd Financial Indicator in overall Financial Market of Pakistan. The Data set for CCG is collected from International Monetary Fund (IMF), World Bank (WB), and International Financial Statistics (IFS). The Proxy for CCG is as under:

Claims on Central Govt. $=$ Claims on Central Govt. $(\%)$ of GDP

\section{Domestic Credit Provided by Economic (DCPFC)}

Economic in the Economy has major role players whose primary activity is to grant loans/credit. Such Financial Institutions provide credit facility to various sectors in the domestic economy like production and services and similar others on gross basis for the development of such industries. Such credit grants are calculated on gross basis while the other which is provided to the Central Government is measured in net. The value of DCPFC is measured as a percentage of Gross Domestic Product. The Data for such indicator is purely 
linked to the Economic and collected from World Development Indicator (WDI) over the period of study.

Domestic Credit Provide by Economic= Domestic Credit Provide by Economic $(\%$ of GDP)

\section{E. Domestic Credit to Private Sector by Bank (DCPSB)}

The last indicator from the Economic in the present study is Domestic Credit to Private Sector by Banks includes all those credit facilities which are purely provided by commercial banking organizations to private sector in the economy over a period. The data for this indicator is also collected from the official website of World Bank as presented in the same proxy; \% of GDP.

Domestic Credit to Private Sector by Banks= Domestic Credit to Private Sector by

$$
\text { Banks (\% of GDP) }
$$

\section{F. Liquidity Management}

Liquidity refers to ability of the business firm to meet its short-term obligations when it becomes due. In the contemporary financial market environment, management of liquidity is very much an important task for managers as it represents the day to day soundness of the business. As per the State Bank of Pakistan SBP, Liquidity Risk is the potential loss arising from inability to full obligations. It can also be defined as position of business of being unable to liquidate a position timely at an appropriate price (Muranaga \& Ohsawa 2002). Firm adopts several techniques to manage the Liquidity to prevent itself from such risk. In the present study, the researchers have collected the data of Liquidity Management in terms ofamount of liquid reserve held by banking firms over time. The data set for main outcome factor is also collected from WDI.

Liquidity Management= Bank's Liquid Reserve to Total Asset Ratio (5)

\section{Econometric Models and Methods}

Data set in the present study includes both the country dynamics and firm specific. So, the models are applied here are of panel data; combination of time series and crosssectional units of observation or entities. In the present study, the time is from 2001-15, and the data for Systematic risk is collected for all the Economic role players in this duration. To check the effect of heterogeneity of the firms, fixed effect model is applied while to generalize the findings beyond the sample used in the model; the random effect is applied. The comparison for both the models is considered through Hausman Test for the fixed- 
random effect. The overall Panel Models can be presented with the help of following Diagram.

Figure 3: Data Analysis Methodology

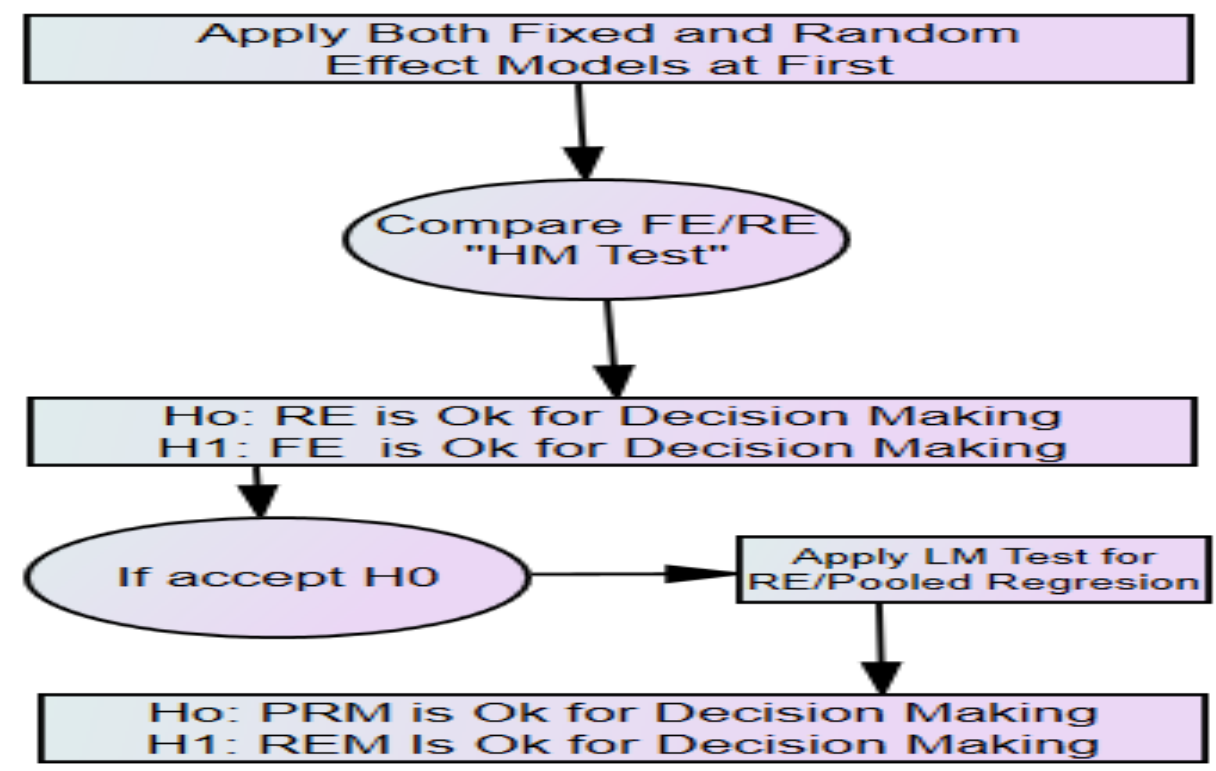

Source: The authors

\section{Findings and Discussion}

Before the testing of model significance through panel data regression, descriptive statistics are obtained to check the trend of data set. Table 1 explains the outcome for all the factors of the study. The mean value for Liquidity Management in terms of Liquidity reserve ratio is positive and highest among the other factors, showing that overall banking organizations have positive reserved value in last 15 years. The range of systematic risk is from -2.51 to 1.41 as per overall market trends with respect to market return and individual return. Table (2) explains the outcomes for the correlation matrix between all the explanatory variables. The overall values of correlation coefficients explain the mixed trend; positive and negative, low, weak, moderate and high with the appropriate significant level. To address either this correlation is problematic or not, Variance inflation factor VIF test is applied.

\section{Table 1: Descriptive Statistics of the Study}




\begin{tabular}{|l|l|l|l|l|}
\hline Variable & Mean & Std. Dev. & Min & Max \\
\hline BLRTAR & 13.46834 & 3.215852 & 9.333856 & 21.13203 \\
\hline SYSTEMATIC RISK & -0.05903 & 0.3396754 & -2.5211 & 1.4164 \\
\hline DIR & 3.348139 & 1.319134 & 2.11625 & 6.828333 \\
\hline COCG & 6.373477 & 5.705795 & -4.4994 & 14.7274 \\
\hline DCPFC & 82.12022 & 5.923145 & 64.99715 & 93.46967 \\
\hline DC2PSBB & 22.31885 & 4.849927 & 15.30144 & 28.73612 \\
\hline
\end{tabular}

Table 2: Correlation Matrix of Variables

\begin{tabular}{|l|l|l|l|l|l|}
\hline & SYS. RISK & DIR & COCG & DCPFC & DC2PSBB \\
\hline SYS. RISK & 1 & & & & \\
\hline DIR & -0.0869 & 1 & & & \\
\hline & $0.0224^{* *}$ & & & & \\
\hline COCG & 0.1053 & -0.6979 & 1 & & \\
\hline & $0.0056^{* *}$ & $0.000^{* *}$ & & & \\
\hline DCPFC & -0.0827 & 0.574 & -0.6294 & 1 & \\
\hline & $0.0299^{* *}$ & $0.000^{* *}$ & $0.000^{* *}$ & & \\
\hline DC2PSBB & -0.0402 & 0.3454 & -0.227 & 0.3776 & 1 \\
\hline & 0.292 & $0.000^{* *}$ & $0.000^{* *}$ & $0.000^{* *}$ & \\
\hline
\end{tabular}

The tolerance level for correlation of all the explanatory factors is presented through Mean VIF which is 1.73 , less than the standard value of 05 , which indicates the fact that there is no high level of correlation and it is in moderate range (Table 3). The value of individual VIF is also less than 05. After addressing the multicollinearity which represents for interdependency among the explanatory factors, panel regression models are applied.

Table 3: VIF Findings

\begin{tabular}{|l|l|l|}
\hline Variables & VIF & $\mathbf{1 / V I F}$ \\
\hline DC2PSBB & 2.34 & 0.426957 \\
\hline DCPFC & 2.17 & 0.461705 \\
\hline COCG & 1.89 & 0.529198 \\
\hline DIR & 1.22 & 0.819661 \\
\hline SYS. RISK & 1.01 & 0.988203 \\
\hline Mean VIF & 1.73 & \\
\hline
\end{tabular}

Table (4) presents the outcomes for the Pooled Regression Model in panel regression. The value of coefficient for systematic risk; beta is -.6853 , explains that unit change in the value of non- diversified risk of selected financial firms has negative impact on the value of liquidity management of overall banking firms in Pakistan. This impact is negative and 
significant as p-value lies in acceptable region. The t-statistics are also in favor for the alternative hypothesis of Systematic Risk and Liquidity Reserve. It means that systematic risk of selected firms negatively affecting to the liquidity reserve of overall banking sector which needs some serious attention. The values of coefficient for all the Economic dynamics like Claims on Central Govt. CCG, and Domestic Credit to Private Sector by Banks DC2PSBB has a negative and significant impact on Liquidity Reserve Ratio of banking industry. While Deposit Interest Rate DIR, and Domestic Credit to Private Sector by Economic DCPFC has significant positive impact on Liquidity Reserve Ratio. As per the findings of Pooled Regression Model PRM, all the explanatory factors have significant outcomes; in favor of research hypothesis that both Economic Dynamics and Systematic Risk consider seriously. For the goodness of model, F-Statistics is checked either all the coefficients are different from zero and statistically significant. The value of F-statistics is significant at $05 \%$, explains that Model is Good fit as all the coefficients are different from zero.

\section{Table 4: Pooled Regression Outcomes}

\begin{tabular}{|c|c|c|c|c|c|}
\hline BLRTAR & Coef. & Std. Err. & $\mathbf{t}$ & $\mathbf{P}>\mathbf{t}$ & [95\% Conf. \\
\hline $\begin{array}{l}\text { SYSTEMATIC } \\
\text { RISK }\end{array}$ & -0.68539 & 0.28247 & -2.43 & $0.016^{* * *}$ & -1.24001 \\
\hline DIR & 0.817362 & 0.106411 & 7.68 & $0.000 * * *$ & 0.608429 \\
\hline COCG & -0.07064 & 0.025583 & -2.76 & $0.006^{* * *}$ & -0.12087 \\
\hline DCPFC & 0.167557 & 0.022136 & 7.57 & $0.000 * * *$ & 0.124094 \\
\hline DC2PSBB & -0.13698 & 0.021722 & -6.31 & $0.000 * * *$ & -0.17963 \\
\hline _cons & 0.439019 & 1.795895 & 0.24 & 0.807 & -3.08711 \\
\hline \multicolumn{6}{|l|}{$F(5,684)=90.55$} \\
\hline \multicolumn{6}{|c|}{ Prob $>\mathrm{F}=0.000 * * *$} \\
\hline \multicolumn{6}{|c|}{ R-squared=.3983 } \\
\hline \multicolumn{6}{|c|}{ Adj. R-squared=.3939 } \\
\hline
\end{tabular}

As per the outcome presented in Table 5 (Fixed Effect Model), all the coefficients have a significant impact on Liquidity Reserve Ratio with both positive and negative impact. Systematic Risk; Beta, COCG, and DC2PSBB has a negative\& significant impact while DIR and DCPFC has a positive and significant impact on BLRTAR. The significance of model is tested through F-test and in favor for the assumption that Fixed Effect Model Findings are also correct with the overall value of R2 of .4037 and adjusted R2 of .3537.

Table 5: Fixed Effect Outcomes 


\begin{tabular}{|c|c|c|c|c|c|}
\hline BLRTAR & Coef. & Std. Err. & $\mathbf{t}$ & $\mathbf{P}>\mathbf{t}$ & [95\% Conf. \\
\hline $\begin{array}{l}\text { SYSTEMATIC } \\
\text { RISK }\end{array}$ & -1.394281 & 0.4149662 & -3.36 & $0.001 * * *$ & -2.209143 \\
\hline DIR & 0.8141093 & 0.1096118 & 7.43 & $0.000 * * *$ & 0.5988666 \\
\hline COCG & -0.0673331 & 0.0263866 & -2.55 & $0.011 * * *$ & -0.119148 \\
\hline DCPFC & 0.1667532 & 0.0228024 & 7.31 & $0.000 * * *$ & 0.1219765 \\
\hline DC2PSBB & -0.1374183 & 0.0223747 & -6.14 & $0.000 * * *$ & -0.1813551 \\
\hline _cons & 0.2596419 & 1.964025 & 0.13 & 0.895 & -3.597081 \\
\hline \multicolumn{6}{|c|}{$F(50,639)=8.36$} \\
\hline \multicolumn{6}{|c|}{ Prob $>\mathrm{F}=0.000 * * *$} \\
\hline \multicolumn{6}{|c|}{ R-squared=.4037 } \\
\hline \multicolumn{6}{|c|}{ Adj R-squared=.3537 } \\
\hline
\end{tabular}

The findings for the random effect model are presented above. All the coefficients are statistically significant and have supported the argument that both Systematic Risk and Economic Dynamics have no valuable impact on Liquidity Reserve of banking sector. The significance of the model is tested through Wald_chi2test, and its findings are also in favor for the assumption that under Random Effect Model, coefficients are statistically different from zero and overall model is good fit (Table 6). To compare the findings for the Fixed and Random Effect Model, Hausman Test is applied.

Table 6: Random Effect Outcomes

\begin{tabular}{|l|l|l|l|l|l|}
\hline BLRTAR & Coef. & Std. Err. & $\mathbf{Z}$ & P>Z & [95\% Conf. \\
\hline SYSTEMATIC RISK & -0.6853946 & 0.2824698 & -2.43 & $0.015^{* *}$ & -1.239025 \\
\hline DIR & 0.8173615 & 0.1064114 & 7.68 & $0.000^{* * *}$ & 0.6087991 \\
\hline COCG & -0.070644 & 0.025583 & -2.76 & $0.006^{* * *}$ & -0.1207857 \\
\hline DCPFC & 0.1675567 & 0.0221359 & 7.57 & $0.000^{* * *}$ & 0.1241711 \\
\hline DC2PSBB & -0.136984 & 0.0217224 & -6.31 & $0.000^{* * *}$ & -0.179559 \\
\hline _cons & 0.4390194 & 1.795895 & 0.24 & 0.807 & -3.08087 \\
\hline Wald chi2(5) $=452.77$ & \multicolumn{5}{|l|}{} \\
\hline Prob > Chi2 $=0.000 * * * *$ \\
\hline
\end{tabular}

The difference in coefficients for both Fixed and Random Effect is presented above with the value of S.E. for the overall significance of HM Test; significance of HM test is tested for the following Hypothesis:

H0: Difference in the Coefficients for the both the Fixed Effect and Random Effect is not Systematic

H1: Difference in the Coefficients for both the Fixed Effect and Random Effect is Systematic 
$\mathrm{b}=$ consistent under Ho and Ha; obtained from

xtreg inconsistent under Ha, efficient under Ho; obtained from xtreg

Test: Ho: difference in coefficients not systematic

$$
\begin{aligned}
& \text { chi2 }(5)=(b-B)^{\prime}\left[\left(V_{-} \_b-V \_B\right)^{\wedge}(-1)\right](b-B)=5.44 \\
& \text { Prob }>\text { chi2 }=0.3648
\end{aligned}
$$

Asp-value is not statistically significant and different from zero, it is supporting the Null hypothesis that Random Effect Model is Ok for Decision Making. For the comparison between Random and Simple OLS Model, Lagrange Multiplier Test as Suggested by Breusch-Pagan is applied. The findings of the test have been examined for the following hypothesis:

H0: OLS Model is Ok for Decision Making

H1: Random Effect Model is Ok for Decision Making

Prob $>$ chi $2=.1065$

So finally, we can suggest that OLS or Pooled Regression Model is Ok for the decision making.

Table 7: Hausman Test Outcomes

\begin{tabular}{|l|l|l|l|l|}
\hline & $(\mathbf{b})$ & $(\mathbf{B})$ & $(\mathbf{b}-\mathbf{B})$ & $\begin{array}{l}\text { Sqrt } \\
\left.\mathbf{V} \_ \text {B) }\right)\end{array}$ \\
\hline & Fixed & Random & Difference & S.E. \\
\hline SYSTEMATIC RISK & -1.394281 & -0.6853946 & -0.7088863 & 0.303986 \\
\hline DIR & 0.8141093 & 0.8173615 & -0.0032522 & 0.026294 \\
\hline COCG & -0.0673331 & -0.070644 & 0.0033109 & 0.006463 \\
\hline DCPFC & 0.1667532 & 0.1675567 & -0.0008035 & 0.005473 \\
\hline DC2PSBB & -0.1374183 & -0.136984 & -0.0004343 & 0.005363 \\
\hline
\end{tabular}

Figure 4: Pooled Regression Output Construct

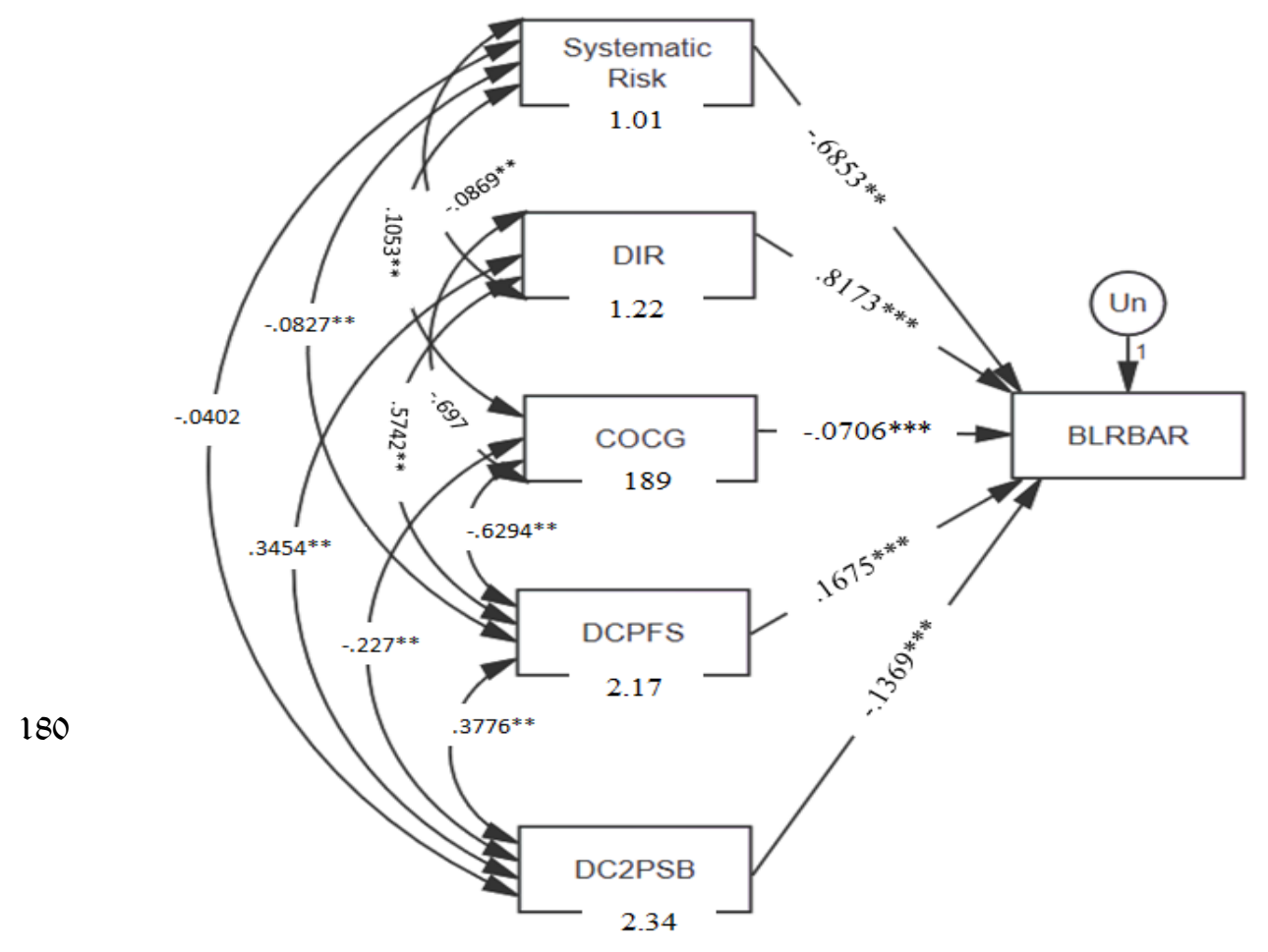




\section{Conclusion}

Liquidity Management is an important and significant indicator for the financial stability of business firms. Variety of factors has changed the liquidity position of both domestic and multinational business corporation. The need of time is to address the issue by considering the key factors in financial environment. Present study is conducted to address this issue and liquidity reserve of banking firms in the context of Pakistan is considered as major outcome factor of the study. Besides, systematic risk for the selected firms has also been calculated over the time period of 2001-15 for the panel regression models. All three models; Fixed Effect, Random Effect, and Pooled Regression, has presented significant findings. The comparison of fixed and random is made through HM test and finally for the random and Pooled Regression is through LM test. The findings are in favor for the Pooled regression that all the explanatory variables are significantly affecting the Liquidity Reserve of Banking firms. Factors like DIR and DCPFS have a significant and positive impact, while Systematic Risk, COCG, and DC2PSB has a significant negative effect over Liquidity Reserve Ratio which needs some serious attention from Managers of Banking Firms. Over the last 15 years, the reserves for Liquidity are in mixed trend. For the stability of these reserves, key decision makers should have to put great focus on these factors and other factors in the financial environment which is not under consideration in present study.

\section{References}

Akhtar, M.F., Ali, K., Sadaqat, S.(2011). Liquidity risk management: a comparative study between conventional and islamic banks of Pakistan. Interdisciplinary Journal of Research in Business, 1(1): 35-44.

Arcand, J.L., Berkes, E., \&Panizza, U.(2015a). Too much finance or statistical illusion: A comment: Graduate Institute of International and Development Studies Working Paper.

Arcand, J.L., Berkes, E., Panizza, U. (2015b). Too much finance? Journal of Economic Growth,20(2): 105-148. 
Arif, A., \&Nauman Anees, A.(2012). Liquidity risk and performance of banking system. Journal of Financial Regulation and Compliance,20(2), 182-195.

Bangia, A., Diebold, F.X., Schuermann,T., \&Stroughai, J.(2008).Modeling liquidity risk with implications for traditional market risk measurement and management. Retrieved August 21, 2017, from https://archive.nyu.edu/bitstream/2451/27135/2/wpa99062.pdf

Barfield, R., \&Venkat, S.(2009). Liquidity risk management. PricewaterhouseCoopers, UK.

Berger, A.N., \&Sedunov, J. (2017). Bank liquidity creation and real economic output. Journal of Banking \& Finance81: 1-19.

Bryant, J.(1980). A model of reserves, bank runs, and deposit insurance. Journal of Banking \& Finance 4(4): 335-344.

Chalermchatvichien, P., Jumreornvong, S., \& Jiraporn, P.(2014) Basel III, capital stability, risk-taking, ownership: Evidence from Asia. Journal of Multinational Financial Management, 28:28-46.

Deep, A., \&Schaefer, G.K.(2004). Are banks liquidity transformers? Retrieved August 14, 2017, from https://papers.ssrn.com/sol3/papers.cfm?abstract_id=556289].

Dembiermont, C., Drehmann, M., \&Muksakunratana, S.(2013). How much does the private sector really borrow? A new Database for total credit to the private non-financial sector. BIS Quarterly Review, 65-81.

Demirgüç-Kunt A., \&Levine, R.(2008). Finance, financial sector policies, and long-run growth. Resea. Work Paper,1:1-82.

DeYoung, R., \&Jang, K.Y.(2016). Do banks actively manage their liquidity? Journal of Banking \& Finance66: 143-161.

Diamond, D.W., \&Dybvig, P.H.(1983). Bank runs, deposit insurance, and liquidity. The Journal of Political Economy,91(3): 401-419.

Drehmann, M., \&Nikolaou, K.(2013). Funding Liquidity Risk: Ddefinition and Measurement. Journal of Banking and Finance,37(7): 2173-2182.

Hong, H., Huang, J-Z., \&Wu, D.(2014). The information content of Basel III liquidityrisk measures. Journal of Financil Stability,15: 91-111.

Howarth, D., \&Quaglia, L.(2016).The comparative Political Economy of Basel III in Europe. Policy andSociety, 35(3): 205-214.

Investopedia (2017). Deposit interest rate. Retrieved August 21, 2017, from http://www.investopedia.com/terms/d/deposit-slip.asp

Jewczyn, N.(2013). Modern portfolio theory, apt, and the capm: The years 1952 to 1986. Intern. Journal of Social Science and Reseach, 2: 74-87.

Kane, S.A.,\&Muzere, M.L.(2005). A model of liquidity and bank reserves.Reseach in Finance, 239-272.

Khan, M.S., Scheule, H., \&Wu, E.(2017). Funding liquidity and bank risk taking. Journal of Banking and Finance,82: 203-216.

King, R.G., \&Levine, R.(1993). Finance, entrepreneurship and growth. Journal of Monetary Economics,32(3), 513-542.

Kuipers, S.K. (1985). Interest rate, savings shortage and liquidity shortage. De Economist, 133(3): 306-326.

Lesmond, D.A.(2005) Liquidity of Emerging Markets. Journal of Financial Economics,77(2): 411-452.

Levine, R., \&Zervos, S.(1998).Stock markets, banks, and economic growth. TheAmerican Economic Review,537-558.

Linnemann, L., \&Schabert, A.(2015). Liquidity Premia and Interest Rate Parity. Journal of International Economic, 97(1): 178-192. 
Logue, D.E., \&Merville, L.J.(1972). Financial policy and market expectations. Financial Management, 37-44.

Muranaga, J. and Ohsawa, M. (2002). Measurement of liquidity risk in the context of market risk calculation", working paper, Institute for Monetary and Economic Studies, Bank of Japan, Tokyo.

Nikolaou, K.(2009). Liquidity (risk) Concepts: Definitions and Interactions. European Central Bank, Working Paper No. 1008.

Pokutta, S., \&Schmaltz, C.(2011). Managing liquidity: optimal degree of centralization.Journal ofBanking \& Finance,35(3): 627-638.

Rubio, M., Rubio, M., Carrasco-Gallego, J.A.,\&Carrasco-Gallego, J.A.(2016). Liquidity, interest rates and house prices in the euro area: a DSGE analysis. Journal of European Real Estate Research, 9(1): 4-25.

Ruozi, R., \&Ferrari, P.(2013) Liquidity Risk Management in Banks: Economic and Regulatory Issues Liquidity Risk Management in Banks: Economic and Regulatory Issues (pp. 1-54). Berlin, Heidelberg: Springer Berlin Heidelberg.

Sensoy, A.(2017). Firm size, ownership structure, and systematic liquidity risk: the case of an emerging market. Journal of Financial Stability, 31:62-80.

Vento, G.A., \&La Ganga, P.(2009). Bank Liquidity Risk Management and Supervision: Which Lessons from Recent Market Turmoil. Journal of Money,Investment and Banking,10(10): 78-125.

Waemustafa, W., \&Sukri, S.(2016). Systematic and unsystematic risk determinants of risk between islamic and conventional banks.International Journal of Economics and Financial Issues,6(4):1321-1327.

Wan, C-f.(2015). Case Study on the Basel II implementation in the United States. Capstone Project. Retrieved March 13, 2018, from https://hub.hku.hk/bitstream/10722/223423/1/FullText.pdf

Wu, Y., Yang, J., \&Zou, Z.(2017). Dynamic corporate investment and liquidity management under model uncertainty. Economics Letters, 155: 9-13. 